\title{
Influence of introduction of cellulosolitic microorganisms on microbiocenosis in conditions of a composting of a poultry excreta
}

\author{
Volkohon V. ${ }^{1}$, Miahka M. ${ }^{2}$, Dimova S. ${ }^{3}$, Derkach S. ${ }^{4}$, Pyrig O. ${ }^{5}$, Lutsenko N. ${ }^{6}$ \\ Institute of agricultural microbiology and agroindustrial production of NAAS, Shevchenko Str., 97, Chernihiv, 14027, \\ Ukraine; e-mail: 'volkogon@ukr.net, ${ }^{2} m g a t s e n k o @ u k r . n e t,{ }^{3}$ dimova13@ukr.net, ${ }^{4}$ derkachsergiy888@gmail.com, \\ 5altrockman1986@gmail.com, ${ }^{6}$ nadija.lutsencko@yandex.ru
}

The purpose. To clarify features of microbiota growth at composting poultry excreta at introduction to substratum of selected cellulosolitic strains of microorganisms. Methods. Laboratory, model, microbiological, gas chromatographic, genetic labeling, statistical. Results. Results of selection of cellulosolitic microorganisms secreted from different organic substrata are brought. After screening in laboratory conditions the strain of bacteria of stem Bacillus (C13) and 3 strains of micromycetes of stem Trichoderma (PD3, 129, L1) which are characterized by tall cellulosolitic activity are taken. On ability of growth in composted substrata on the basis of poultry excreta, as well as influence on formation of groups of microorganisms (first of all, growth of numerosity micromycetes and cellulosolitic bacteria) it is necessary to consider as perspective strains Bacillus sp. C13 and Trichoderma sp. PD3. Besides, these strains promote mineralization of organic substance during composting. Their introduction to composted substrata enables to diminish duration of fermentation of compost and to enrich it agronomically valuable microorganisms. Conclusions. Use of active strains of microorganisms at composting organic substance is a perspective method of control over microbiological processes destruction. Thus composts during fermentation can be agronomically enriched with valuable microorganisms and products of their metabolism. The composts gained thus at their application in techniques of growing crops can influence positively productivity of agroecosystems not only as a source of biogenic elements, but also as biological inducer of processes of growth and development of plants.

Key words: introduction of microorganisms, compost, poultry excreta, microbial succession, cellulose breaking microorganisms, Bacillus sp., Trichoderma sp.

DOI: https://doi.org/10.31073/agrovisnyk201905-06

Composting is an aerobic process as the result of which the organic matter undergoes partial mineralization and a deep transformation due to the metabolism of organisms that develop in a composted substrate. Although composting is a microbiological process, existing technologies of converting of organic matter practically do not take into account its microbiological peculiarities. Identification of the diversity and structure of groups of compost microorganisms is of substantial interest to researchers, primarily for solving a number of environmental issues [1] - [2]. In addition, the study of the characteristics of microorganisms successions in composted substrates is essential for the efficient composting process operation, since bacteria and microscopic fungi play a key role in this process, and the emergence of some microorganisms reflects the quality of maturating compost [3] - [4].

Previously, we have investigated changes in the number of microorganisms of certain ecological trophic groups during the composting of chicken litter with an optimized $\mathrm{C}: \mathrm{N}$ ratio (with the introduction of straw and peat in the estimated quantities) [5]. But the presence in the composted substrate difficultly fermented component (straw) causes a rather durable process of composting. Therefore, in order to accelerate the fermentation of organic matter, it is advisable to introduce cellulose-destroying microorganisms to composted substrates. However, it is unclear how other microorganisms including cellulosolytic, will develop under such conditions. 
The purpose of the research is the selection of cellulosolytic microorganisms capable for active development in composted mixtures based on chicken litter, positive effect on the succession of microorganisms and straw destruction in conditions of composting.

Methods of research.. Selection of cellulose destructors was carried out in laboratory conditions with usage of mediums in which the only source of carbon is cellulose. With that the micromycetes were isolated and cultivated in accordance with existing methodological developments [11] - [12].

The classical approach was used for identification of the cellulosolytic activity of micromycetes [10]. The fungi were cultiveted on Czapek-Dox medium of the following composition $\left(\mathrm{g} / \mathrm{dm}^{3}\right): \mathrm{NH}_{4} \mathrm{NO}_{3}-2 ; \mathrm{K}_{2} \mathrm{HPO}_{4}-1,0$; $\mathrm{MgSO}_{4}-0,5 ; \mathrm{KCl}-0,5 ; \mathrm{FeSO}_{4} \times 7 \mathrm{H}_{2} \mathrm{O}-0,001 ; \mathrm{pH}-4,5-5$. Wheat straw and filter paper (1\% of weight) were used as the only source of carbon supply. After 21 days of cultivation, the remnants of the cellulosic substrate were separated from the culture liquid and dried, the destruction percentage was counted.

During the selection of active cellulose-destroying isolates of bacteria and fungi, as the positive control were used available cellulosolytic strains - Bacillus subtilis Ehrenberg IMB B-7516, Trichoderma harzianum Rifai F2455, Trichoderma viride Pers F 100001, which were provided by depository of D.K. Zabolotny Institute of Microbiology and Virology of the NASU.

The study of establishment and development of microorganisms introduced to compost and the investigation of succession of microorganisms were carried out during the composting of chicken manure with selective cellulose destructive microorganisms under the conditions of model experiments. Composting was carried out in plastic containers, where $5 \mathrm{~kg}$ of chicken litter with a humidity of $70 \%$ was placed. In order to optimize the ratio of C:N at the level of 20: 1 to the litter was added shredded straw in the amount of $0.7 \mathrm{~kg}$ and $1.9 \mathrm{~kg}$ peat. The number of experiment replication is four. During composting, the substrate humidity was kept at a level from $70 \%$ to $75 \%$, with stirring once for every two weeks.

Bacteria were grown under conditions of batch culture on the growth medium of the following composition $\left(\mathrm{g} / \mathrm{dm}^{3}\right)$ : molasses $(50 \%)-30 ;\left(\mathrm{NH}_{4}\right)_{2} \mathrm{SO}_{4}-0,1 ; \mathrm{KH}_{2} \mathrm{PO}_{4}-0,25 ; \mathrm{K}_{2} \mathrm{HPO}_{4}-0,25 ; \mathrm{MgSO}_{4}-0,25 ; \mathrm{CaCO}_{3}-0,3$; $\mathrm{pH}-7,0$. Spore mycelial suspension of fungi was obtained by growing on a slant wort agar in test tubes, with following wash off with sterile water.

The introduction of microorganisms into composted mixtures was carried out after 2 months of their previous fermentation at the rate of $1 \times 10^{6}$ bacteria cells $/ \mathrm{g}$ of compost, micromycetes $-1 \times 10^{5} \mathrm{CFU} / \mathrm{g}$ of compost. Survival ability and development of bacteria introduced into substrates were determined using the genetic marking method [9]. Resistant strains of bacillus, able to develop in a medium with streptomycin at a dose of $2,000 \mu \mathrm{g} / \mathrm{ml}$ were obtained. Isolates of the investigated micromycetes were not genetically labeled due to the absence of representatives of the genus Trichoderma Pers. in the compost substrates and the possibility of their simple identification on the nutrient medium.

The scheme of experiment on composting chicken litter blends with peat and straw under the influence of selected cellulose-destroying microorganisms included the following options:

1. Control (mixture of litter with peat and straw)

Composting a mixture of litter with peat and straw affected by:

2. Bacillus sp. СБ 1

3. Bacillus sp. C 13

4. Trichoderma sp. PD 3

5. Trichoderma sp. $Л 1$

6. Trichoderma sp. 129.

The number of ammonifying bacteria was defined on meat-and-peptone agar, microorganisms, which mainly absorb the mineral forms of Nitrogen was determined on starch-and-ammonia agar, micromycetes - on wortagar [6]. The number of cellulose destructing bacteria was studied on liquid Imshenetskyi and Solntseva medium [7]. For evaluation of carbon dioxide emissions, the method of closed chambers was used [8]. The emission of $\mathrm{CO}_{2}$ in the compost was determined in gas samples on a gas chromatograph "Tsvet - $500 \mathrm{M}$ " with a heat conductivity detector. 
Statistical processing of results was performed using dispersion analysis. The results of model experiments were calculated with the help of two-factor dispersion method and using a computer program (Microsoft Office Excel 2003-2010).

Results of the research. For a purpose of screening of cellulose-destroying microorganisms, isolates were extracted from different substrates (chicken litter, compost based on chicken manure, biohumus, hay, halfdecay leaves, soil). There were selected 243 isolates of bacteria, which were initially classified as Bacillus genus, and 144 isolates of micromycetes identified as representatives of Trichoderma genus (further in the text introduced the results of only a part of isolates which interesting from the point of view of their potential).

In order to select isolates with high cellulosolytic activity, there were carried out the investigations of the destruction degree of straw and filter paper as the only source of carbon in the mineral medium. Among the isolated bacteria, the most active in the destruction of filter paper were isolates: Bacillus sp. 14/7, Bacillus $s p$. $17 / 7$,

Bacillus sp. C13, Bacillus sp. 14/1, Bacillus sp. СБ1 (the degree of destruction of filter paper is from $12,5 \%$ to $28,6 \%$ ) (Table 1).

Table 1 - Degree of destruction of filter paper and straw by representatives of the genus Bacillus

\begin{tabular}{|l|l|l|l|}
\hline \multirow{2}{*}{ Microorganisms } & \multirow{2}{*}{ Extraction source } & \multicolumn{2}{|l|}{ Destruction degree of } \\
\cline { 3 - 4 } & & filter paper, \% & straw, \% \\
\hline $\begin{array}{l}\text { Bacillussubtilis IMB } \\
\text { B-7516 }\end{array}$ & Collection strain (standard) & 20,1 & 7,7 \\
\hline Bacillus sp. 4/1 & compost based on chicken manure & 11,2 & 5,1 \\
\hline Bacillus sp. 4/3 & compost based on chicken manure & 4,8 & 5,2 \\
\hline Bacillus sp. 14/1 & wood chopped by bark beetle & 13 & 7,6 \\
\hline Bacillus sp. 14/6 & biohumus & 4,4 & 5,1 \\
\hline Bacillus sp. 14/7 & biohumus & $\mathbf{2 8 , 6}$ & $\mathbf{1 1 , 5}$ \\
\hline Bacillus sp. 15/2 & hay (mixed herbs) & 0,8 & 4,6 \\
\hline Bacillus sp. 17/1 & half-decayed leaves (mixed herbs) & - & 1,9 \\
\hline Bacillus sp. 17/7 & hay (mixed herbs) & $\mathbf{2 4 , 0}$ & $\mathbf{7 , 8}$ \\
\hline Bacillus sp. 20/6 & biohumus & 3,6 & 6,7 \\
\hline Bacillus sp. 22/1 & chicken manure & - & 3,6 \\
\hline Bacillus sp. C13 & soil & $\mathbf{1 3 , 9}$ & $\mathbf{1 5 , 5}$ \\
\hline Bacillus sp.CБ1 & hay (mixed herbs) & $\mathbf{1 2 , 5}$ & $\mathbf{1 1 , 3}$ \\
\hline
\end{tabular}

Note: the most active isolates of bacteria are highlighted in bold.

Regarding straw decomposition, the highest destruction rates of the research were observed while using Bacillus sp. 14/7, Bacillus sp. C13 and Bacillus sp. СБ1 (from 11,3\% to 15,5\%). Influence of Bacillus sp. 14/1 and Bacillus sp. $17 / 7$ is slightly lower for straw decomposition $(7,6-7,8 \%)$. It should be noted that the intensity of the destruction of filter paper and straw with active isolates was higher than the positive control rates (Bacillus subtilis IMB B-7516).

For further studies, there were used bacteria, under influence of which the greatest degree of destruction of filter paper and / or straw was observed (Bacillus sp. 14/7, Bacillus sp. 17/7, Bacillus sp. С13, Bacillus sp. СБ1).

While studying cellulosolytic activity of micromycetes, the research was conducted on a mineral medium with straw. Activity was compared with the performance of strains Trichoderma harzianum F-2455 and T. viride $\mathrm{F}$ 100001.

The highest activity regarding decomposition of straw as the only source of carbon in the mineral medium was demonstrated by isolates of Trichoderma sp. PD 3, 13, 129, Л 1 (Table 2). Under influence of these isolates the degree of straw destruction is $34-38 \%$, which exceeds the positive control rates $-T$. harzianum F-2455 and T. viride $\mathrm{F} 100001$ (25\% and $26 \%$ respectively). 
Table 2 - Activity of destruction of filter paper with isolated micromycetes of the genus Trichoderma

\begin{tabular}{|c|c|c|}
\hline Microorganisms & Source of extraction & $\begin{array}{l}\text { The degree of the straw } \\
\text { destruction, } \%\end{array}$ \\
\hline Trichoderma harzianum F-2455 & Collection strain (standard) & 25 \\
\hline Trichoderma viride F 100001 & Collection strain (standard) & 26 \\
\hline Trichoderma sp. 1 & roots of birch & 26 \\
\hline Trichoderma sp. 2 & $-/ /-$ & 26 \\
\hline Trichoderma sp. 3 & $-/ /-$ & 29 \\
\hline Trichoderma sp. 13 & $-1 /-$ & 38 \\
\hline Trichoderma sp. 18 & $-1 /-$ & 29 \\
\hline Trichoderma sp. PD3 & $-/ /-$ & 33 \\
\hline Trichoderma sp. 115 & half-decayed straw & 33 \\
\hline Trichoderma sp. 127 & $-/ /-$ & 23 \\
\hline Trichoderma sp. 128 & $-/ /-$ & 30 \\
\hline Trichoderma sp. 129 & $-1 / /-$ & 34 \\
\hline Trichoderma sp. 140 & $-/ /-$ & 30 \\
\hline Trichoderma sp. Л 1 & half-decayed leaves & 37 \\
\hline
\end{tabular}

Note: the most active bacterial isolates are highlighted in bold.

On the basis of the obtained results, for the further study of straw destruction during the composting the isolates of Trichoderma sp. PD 3, 13, 129, $л 1$ were selected, as the most active cellulose-destructive micromycetes under laboratory conditions.

Selected active cellulosolytic isolates of bacteria of the genus Bacillus $(14 / 7,17 / 7$, C13, СБ1) and fungi of the genus Trichoderma (PD 3, 13, 129. Л 1) were tested for the ability to develop in organic substrates based on poultry manure.

Adapted for resistance to streptomycin (as a marker that allows identifying the introduced bacteria) at a dose of $2000 \mu \mathrm{g} / \mathrm{ml}$, strains of bacteria were introduced into the compost mixture after 2 months of preliminary composting. The obtained data show the reproduction of certain bacterial strains in composted substrates at the initial stages of composting. It is worth noting that $\mathrm{C} 13$ strain had rather high degree of the development in the substrate based on poultry manure. Thus, throughout all of the period of composting, the number of streptomycin-resistant bacteria Bacillus sp. C 13 was at a level not less than 5 million CFU / g of dry substrate.

The ability of isolated active strains of micromycetes to develop in composted substrates was also determined. The obtained results show the successful introduction of the majority of studied strains to the composted substrates. Thus, in the mixture of litter with straw and peat, the best survival was shown by strain PD3, the number of which during the composting period increased from 13,3 to 125 thousand CFU/g of dry compost. Also, persistently high rates were noted while the introduction to the compost isolates of Trichoderma $s p . \Omega 1$ and Trichoderma sp. 129 (60 - 70 thousand CFU / $g$ dry compost from 60th day to the end of composting).

Thus, in the course of the conducted work, there were selected one bacteria strain of the genus Bacillus (C 13) and three fungi strains of the genus Trichoderma (PD 3, 129, Л 1), which are characterized by high cellulosolytic activity and ability to develop in the composting substrates based on chicken manure.

The next stage of our research was finding out the peculiarities of succession changes in the groups of microorganisms while the composting of chicken manure with the introduction of selected strains of cellulosolytic microorganisms.

The obtained results confirm the growth in the composted substrates of the number of bacteria that are directly involved in the transformation processes of Nitrogen. Thus, while the introduction of selected microorganisms there was increase of the number of ammonifying bacteria and microorganisms that mainly absorb the mineral forms of Nitrogen. At the same time, the number of ammonifiers is the highest during $3-4$ months (90-120 days) and 6 months (180 days) of composting (Fig. 1). Thus, in the variants with the introduction to compost of Trichoderma sp. PD 3 and Trichoderma sp. PD 3, their number increases from 1,1 billion CFU/g of compost on the 2nd month of composting to $1,6-1,80$ billion CFU/g of compost on the $3 r d-4^{\text {th }}$ months. After six months of composting, there is another increase of the quantity of ammonifying bacteria - up to 3,54 billion CFU/g of compost. Consequently, there are two peaks of development of these microorganisms, which is explained by the heterogeneity of the organic substrate and longstanding mineralization a of some of its components. 


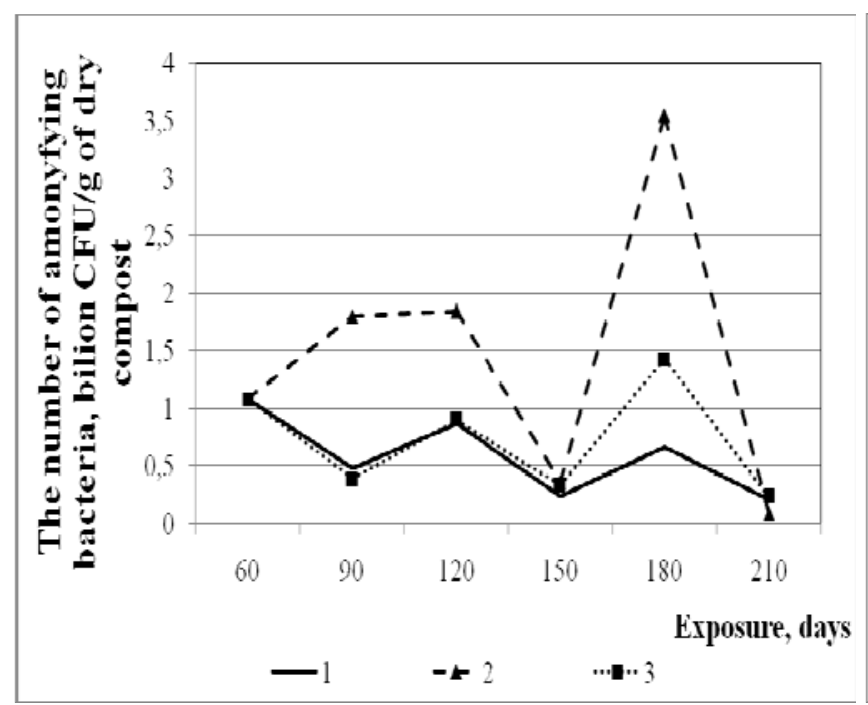

1 - Control (mixture of litter with peat and straw)

Composting under the influence of:

2 - Bacillus sp. СБ 1 ;

3 - Bacillus sp. C 13.

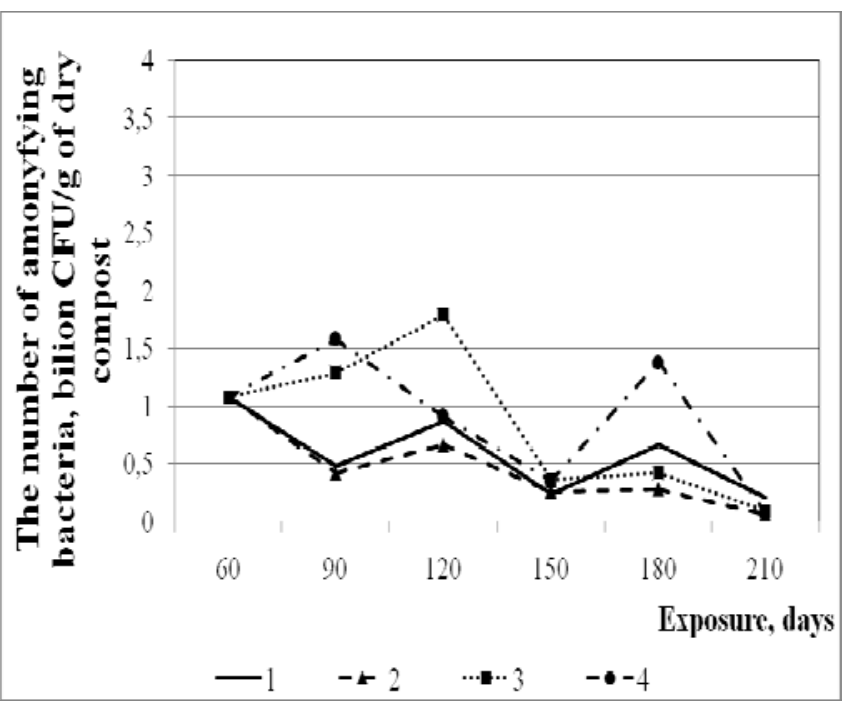

1 - Control (mixture of litter with peat and straw)

Composting under the influence of:

2 - Trichoderma sp.PD 3;

3 - Trichoderma sp. Л 1;

4 - Trichoderma sp. 129.

Fig. 1. Dynamics of the number of ammonifying microorganisms in the compost based on chicken litter, depending on the introduced microorganism.

While composting litter with straw and peat, with the participation of all investigated representatives of the genus Trichoderma, the rapid development of microorganisms that take up mainly mineral forms of Nitrogen is observed during the 3rd month of composting (Table 3). Their number grows from 0,85 billion CFU/g of dry compost (2nd month of composting) to 4,10 billion CFU/g of dry compost (3rd month of composting). After this period of growth, a sharp decrease in their number is observed, which is explained by the decrease of the trophic substrate (as mineral nitrogen compounds released in the process of mineralization with the participation of microorganisms are transformed into new organic compounds). Slightly below are the rates of the number of representatives of this microorganisms group in composting variants with participation of bacteria of the genus Bacillus.

Table 3 - Dynamics of the number of bacteria which use mainly mineral forms of Nitrogen (billion CFU / $g$ of compost)

\begin{tabular}{|c|c|c|c|c|c|c|}
\hline \multirow[b]{2}{*}{ Experiment variants } & \multicolumn{6}{|l|}{ Exposure duration } \\
\hline & $\begin{array}{l}2 \text { months of } \\
\text { composting } \\
\text { (before the } \\
\text { introduction of } \\
\text { microorganisms) }\end{array}$ & 3 months & 4 months & 5 months & 6 months & 7 months \\
\hline $\begin{array}{l}\text { Control (mixture of } \\
\text { litter with peat and } \\
\text { straw) }\end{array}$ & $0,85 \pm 0,9$ & $0,8 \pm 0,1$ & $0,9 \pm 0,1$ & $0,2 \pm 0,01$ & $0,1 \pm 0,02$ & $\begin{array}{l}0,06 \pm 0,00 \\
4\end{array}$ \\
\hline \multicolumn{7}{|c|}{ Composting under the influence of } \\
\hline Bacillus sp. СБ 1 & & $0,8 \pm 0,10$ & $0,5 \pm 0,04$ & $0,3 \pm 0,04$ & $0,2 \pm 0,02$ & $0,1 \pm 0,01$ \\
\hline Bacillus sp. C13 & & $0,4 \pm 0,05$ & $0,5 \pm 0,04$ & $0,4 \pm 0,05$ & $0,4 \pm 0,02$ & $0,1 \pm 0,02$ \\
\hline Trichoderma sp. PD3 & & $3,5 \pm 0,10$ & $0,2 \pm 0,02$ & $0,3 \pm 0,05$ & $0,3 \pm 0,03$ & $0,1 \pm 0,02$ \\
\hline Trichoderma sp.Л 1 & & $3,7 \pm 0,80$ & $0,5 \pm 0,10$ & $0,1 \pm 0,02$ & $0,2 \pm 0,04$ & $0,04 \pm 0$ \\
\hline Trichoderma sp. 129 & & $4,1 \pm 0,40$ & $0,1 \pm 0,01$ & $0,9 \pm 0,02$ & $0,2 \pm 0,03$ & $0,02 \pm 0$ \\
\hline
\end{tabular}

The dynamics of the micromycetes number in the composted mixture with the introduction of bacilli is characterized by a gradual insignificant increase, which can be explained by the active development of the introduced bacterium, and partial inhibition of the development of micromycetes. 
The introduction of Trichoderma into the composting substrate initially shows an increase in the number of micromycetes, later the number stabilizes at a certain level. Thus, the increase in the number of microscopic fungi begins with 0,5 million CFU/g (2nd month of composting) and reaches 1,03-2,7 million CFU/g of dry compost depending on the investigated strain (Fig. 2). The highest number of micromycetes is observed while the introduction Trichoderma sp. PD 3into the composted mixture of, which may indirectly show the active development of the introduced micromycet in the substrate.

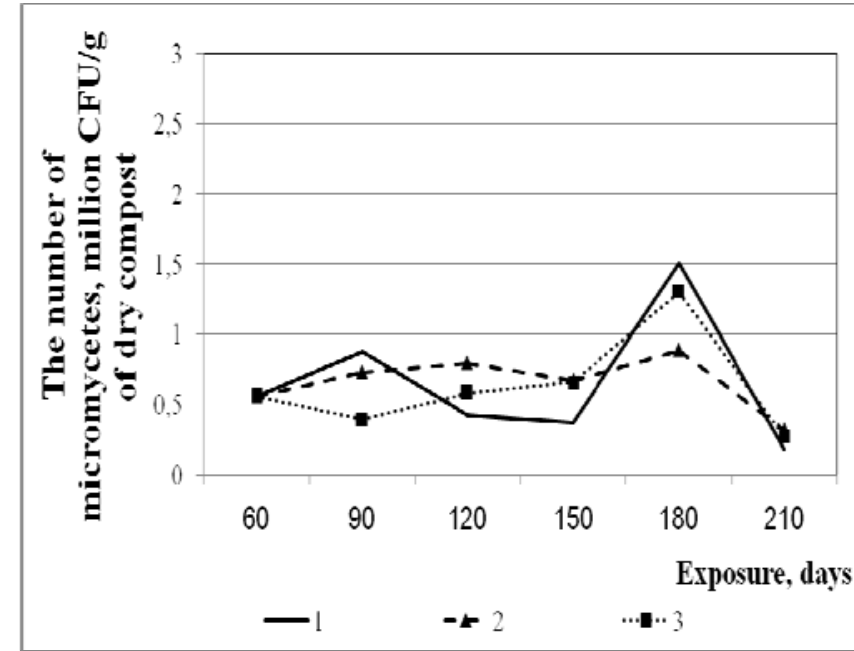

1 - Control (mixture of litter with peat and straw)

Composting under the influence of:

2 - Bacillus sp. СБ 1;

3 - Bacillus sp. C 13.

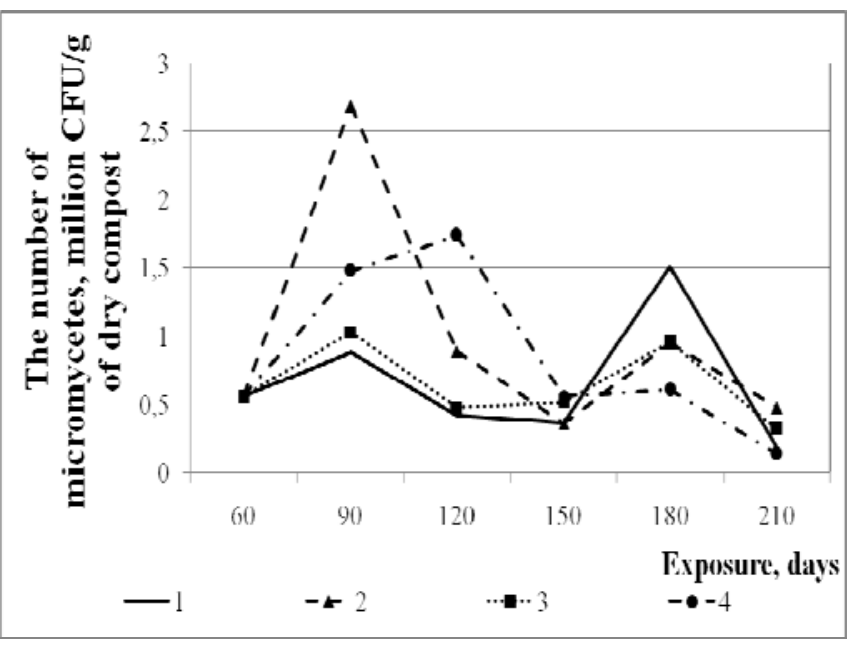

1 - Control (mixture of litter with peat and straw) Composting under the influence of:

2 - Trichoderma sp.PD 3;

3 - Trichoderma sp. Л 1;

4 - Trichoderma sp. 129.

Fig. 2. Dynamics of the number of micromycetes in compost based on chicken litter depending on the introduced microorganism.

The study of the number of the cellulosolytic aerobic bacteria indicates an increase in their amount in the substrate after 3 months of composting. The highest rates of cellulose destroying bacteria - up to 39 million CFU/g of dry compost are noted with the introduction into the mixture of Bacillus sp. C 13 (Fig. 3).

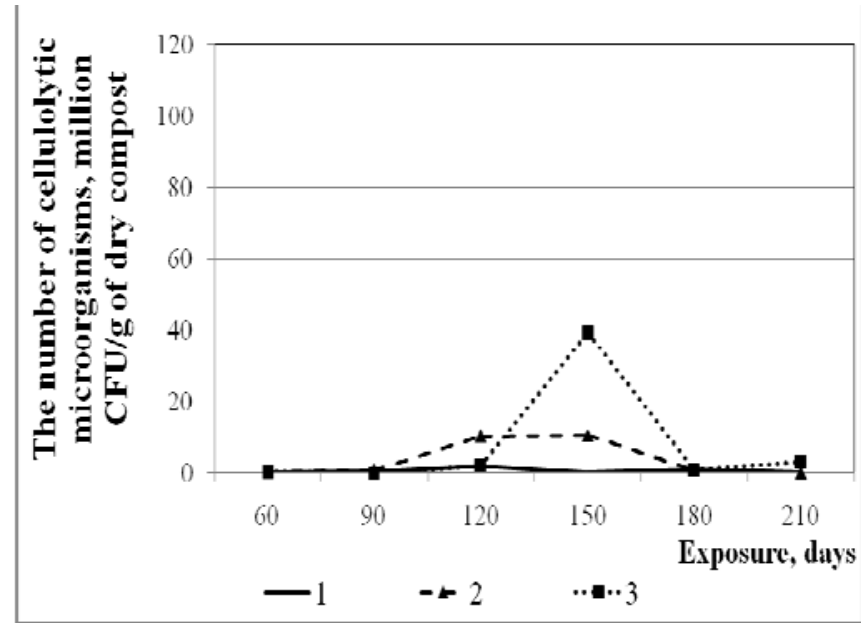

1 - Control (mixture of litter with peat and straw)

Composting under the influence of:

2 - Bacillus sp. СБ 1;

3 - Bacillus sp. C 13.

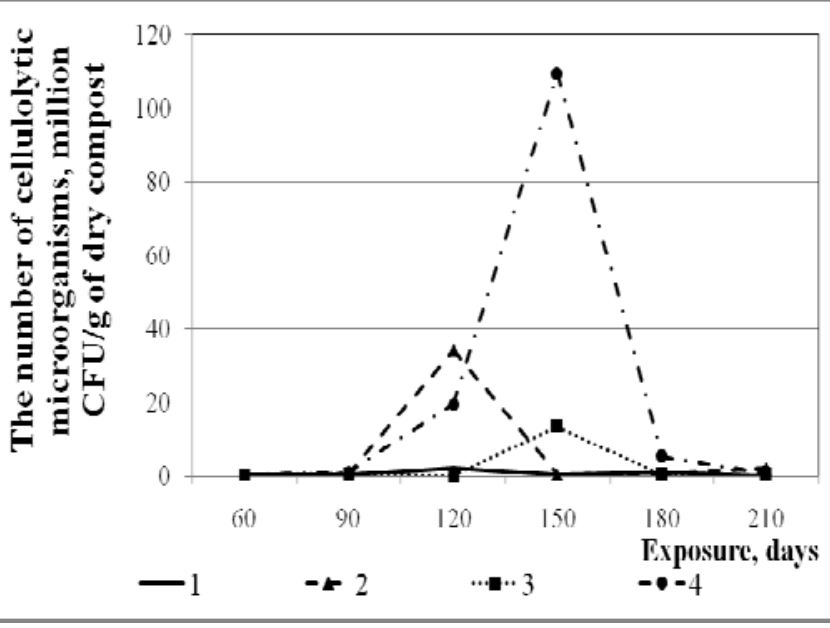

1 - Control (mixture of litter with peat and straw) Composting under the influence of:

2 - Trichoderma sp.PD 3;

3 - Trichoderma sp. Л 1;

4 - Trichoderma sp. 129.

Fig. 3. Peculiarities of the development of cellulosolytic aerobic bacteria in compost based on chicken litter depending on the introduced microorganism 
While composting the mixture based on litter with micromycetes of the genus Trichoderma, the increase of the number of cellulosolytic bacteria along with a gradual decrease in the number of fungi is observed. Interestingly, the introduction of Trichoderma sp. 129 to the compacted substrate contributes to the greatest development of cellulosic bacteria - up to 109,3 million CFU/g of dry compost.

The final stage of composting is characterized by a decrease in the number of representatives of all studied groups of microorganisms (to the lowest rates of the whole period of composting). This is logical, since the organic matter in the substrate has undergone a complete mineralization and synthesis of new organic compounds, which limited the sources of nutrition for the development of the studied microorganisms. According to these microbiological rates, the composting period can be considered as completed.

An integrated index of the development of microorganisms may be the production of $\mathrm{CO}_{2}$. The graphs of carbon dioxide emission generally characterize the peculiarities of composting processes. Thus, the highest rates of $\mathrm{CO}_{2}$ emission are observed in the compost after the introduction of Bacillus sp. C 13 and Trichoderma sp. PD 3 (Table 4).

Table 4 - Dynamics of carbon dioxide emissions from composted substrates, $\mathrm{nmol} \mathrm{CO}_{2} / \mathrm{g}$ of compost/hour

\begin{tabular}{|c|c|c|c|c|c|c|}
\hline \multirow[b]{2}{*}{ Experiment variants } & \multicolumn{6}{|l|}{ Exposure duration } \\
\hline & $\begin{array}{l}2 \text { months of } \\
\text { composting } \\
\text { (before the } \\
\text { introduction of } \\
\text { microorganisms) }\end{array}$ & 3 months & 4 months & 5 months & 6 months & 7 months \\
\hline $\begin{array}{l}\text { Control (mixture of } \\
\text { litter with peat and } \\
\text { straw) }\end{array}$ & $174,9 \pm 11,6$ & $143,7 \pm 4,4$ & $114,8 \pm 10,2$ & $100,8 \pm 4,6$ & $27,3 \pm 2,9$ & $8,72 \pm 0,38$ \\
\hline \multicolumn{7}{|c|}{ Composting under the influence of } \\
\hline Bacillus sp. СБ 1 & & $149,5 \pm 5,1$ & $112,0 \pm 1,3$ & $195,1 \pm 2,3$ & $70,5 \pm 2,4$ & $6,29 \pm 0,7$ \\
\hline Bacillus $s p$. C13 & & $388,1 \pm 8,7$ & $171,2 \pm 1,8$ & $150,5 \pm 2,3$ & $68,9 \pm 5,7$ & $2,61 \pm 0,3$ \\
\hline Trichoderma sp. PD3 & & $36,1 \pm 0,8$ & $67,7 \pm 0,3$ & $263,5 \pm 3,9$ & $72,1 \pm 1,5$ & $4,23 \pm 0,2$ \\
\hline Trichoderma sp.Л 1 & & $41,2 \pm 2,2$ & $69,7 \pm 0,9$ & $130,9 \pm 2,9$ & $65,6 \pm 1,9$ & $2,17 \pm 0,2$ \\
\hline Trichoderma sp. 129 & & $22,7 \pm 2,9$ & $61,9 \pm 1,2$ & $154,7 \pm 3,3$ & $16,6 \pm 0,9$ & $1,40 \pm 0,2$ \\
\hline
\end{tabular}

At the end of the composting period, the production of $\mathrm{CO}_{2}$ is reduced, which may also indicate the completion of the process of organic matter fermentation.

Investigation of the influence of introduced microorganisms on the degree of straw destruction under composting conditions indicates the highest rates of straw fermentation under introducing to the substrates Bacillus sp. C 13 and Trichoderma sp. PD 3 (which are $60 \%$ and $72 \%$ respectively) (Table 5).

Table 5 - Degree of straw destruction at the final stage of chicken litter composting

\begin{tabular}{|l|l|}
\hline Experiment variants & The degree of the straw destruction, $\%$ \\
\hline Control (mixture of litter with peat and straw) & 48 \\
\hline Composting under the influence of & 54 \\
\hline Bacillus $s p$. СБ 1 & 60 \\
\hline Bacillus $s p$. C13 & 72 \\
\hline Trichoderma $s p$. PD3 & 53 \\
\hline Trichoderma $s p$. . 1 & 57 \\
\hline Trichoderma $s p .129$ &
\end{tabular}

\section{Conclusions}

The obtained results of laboratory and model experiments on the composting of substrate based on chicken litter with the participation of selected cellulosolytic microorganisms demonstrate the prospects of Bacillus $s p$. C 13 and Trichoderma sp. PD 3 as biological agents for the optimization of the processes of biofermentation of organic matter. 


\section{References}

1. Tiquia S.M., Michel Jr. F.C (2002). Diversity in Livestock manure compost as characterized by terminal restriction fragment length polymorphisms (T-RFLP) of PCRamplified 16S rRNA gene sequences: Microbiology of Composting. $636 \mathrm{p}$.

2. Anastasi A., Varese G. C, Marchisio V. F. (2005). Isolation and identification of fungal communities in compost and vermicompost. Mycologia. Vol. 97. P. 33-44. doi.org/10.1080/15572536.2006.11832836

3. Sánchez Ó.J., Ospina D.A., Montoya S. (2017).Compost supplementation with nutrients and microorganisms in composting process. Waste Manag. № 69. P. 136-153. doi: 10.1016/j.wasman.2017.08.012.

4. Ribeiro N. de Q., Souza T. P., Costa L. M. A. S., de Castro C. P., Dias E. S. (2017). Microbial additives in the composting process. Ciênc. agrotec. Vol.41. № 2. P. 159-168. doi.org/10.1590/1413-70542017412038216.

5. Myagka M., Derkach S., Volkogon V., Lutsenko N. (2014). Suktsesii mikroorhanismiv u protsesi kompostuvannia kuriachoho poslidu. [The successions of microorganisms in the process of chicken litter composting]. Agricultural microbiology. No.20. P. 3-7. [in Ukrainian].

6. Dudka I.A., Vasser S.P., Ellanskaya I.A. et al. (Bylai V.I., Ed). (1982). Metody eksperementalnoy mikologii. [Methods of experimental mycology]. Kiev: Nauk. Dumka. 561 p. [in Russian].

7. Avdieieva L., Kharkhota M., Kharkhota G. (2016). Destruktsia pozhyvnykh roslynnykh zalyshkiv shtamamy B. subtilis IMB B-7516 i B. Licheniformis MB B-7515 [Destruction of postharvest vegetal remainders by strains B. subtilis IMV V-7516 i B. Licheniformis MV V-7515]. Microbiological journal. No.2. P. 14-19. [in Ukrainian].

8. Hogos S.E.G., Juarez J.V., Ramonet C.A., Lopeg J.G., Rios A.A., Uribe E.G. (2002). Aerobic thermophilic composting of wastesludge from gelating-grenetine industry. Resurces Conservationand Recycling. V. 34, Is.3. P. 161-173 (Scopus).

9. Gerkhardt F. (Ad). (1984). Metody obshchiei bakteriologii. [Methods of general bacteriology]. Moskva: Mir. 264 p. [in Russian].

10. Tepper E., Shylnikova V., Pereverzeva G. (1987). Praktikum po mikrobiokogii. [Microbiology manual]. Moskva: Agropromizdat. 239 p. [in Russian].

11. Zviagintsev D.T. (1980). Metody pochvennoi mikrobiologii I biokhimii. . [Methods of soil microbiology and biological chemistry]. Moskva: Izdatelstvo MGU. 224p. [in Russian].

12. Kusa K., Sawamoto T., Hu R. (2008). Comparison of the closed-chamber and gas concentration gradient methods for measurement of $\mathrm{CO}_{2}$ and $\mathrm{N}_{2} \mathrm{O}$ fluxes in two upland field soils. Soil Science and Plant Nutrition. No. 54. P. 777-785. doi.org/10.1111/j.1747-0765.2008.00292.x 